\title{
SYNTHESIS AND CHARACTERIZATION OF NOVEL 1,2,3-TRIAZOLE-BRIDGED OXIME POLYURETHANES OBTAINED FROM AN ISOMANNIDE DERIVATIVE
}

\author{
Fatih Bayrak ${ }^{1}$, Ayhan Oral ${ }^{2}$, Kadir Ay ${ }^{*}$ \\ ${ }^{1}$ Department of Chemistry, Faculty of Arts and Sciences, Manisa Celal Bayar University, Manisa, Turkey \\ ${ }^{2}$ Department of Chemistry, Faculty of Arts and Sciences, Çanakkale Onsekiz Mart University, \\ Çanakkale, Turkey \\ kadir.ay@cbu.edu.tr
}

Polyurethanes (PUs) are synthesized by the reaction of diisocyanates and diols and are widely used in furniture foams, thermal insulation, coatings, and adhesives. In this work, a 1,2,3-triazole-bridged dioxime (compound 6) as a diol source was synthesized from isomannide via tosylation, azidation, and cyclization-addition and used in the syntheses of new PUs. A new carbohydrate-based linear P-1 was synthesized by the reaction of $\mathbf{6}$ and 1,6-hexamethylene diisocyanate (1,6-HMDI). Besides, three new linear PUs (P-2, P-3, and P-4) were synthesized by the reaction of $\mathbf{6}$, isomannide compound (used in different molar ratios), and 1,6-HMDI. The thermal properties of the new PUs were determined by thermogravimetry (TG), their molecular structures were characterized by FTIR, ${ }^{1} \mathrm{H}-$ and ${ }^{13} \mathrm{C}-\mathrm{NMR}$, and the molecular weights of some polymers were determined by GPC/SEC. Additionally, the surface characteristics of the synthesized PUs were examined via scanning electron microscopy (SEM).

Keywords: poly(oxime-urethane), polyurethane, 1,6-hexamethylene diisocyanate, isomannide, azide, dioxime, 1,2,3-triazole

\section{СИНТЕЗА И КАРАКТЕРИЗАЦИЈА НА НОВИ 1,2,3-ТРИАЗОЛ-МОСТОВНИ ОКСИМ-ПОЛИУРЕТАНИ ДОБИЕНИ ОД ДЕРИВАТ НА ИЗОМАНИД}

Полиуретаните (PUs) се синтетизираат во реакција на диизоцијанати и диоли, а широко се користат во пени за мебел, термичка изолација, премази и лепила. Во овој труд 1,2,3-триазолмостовен диоксим (соединение 6) како извор на диол беше синтетизиан од изоманид преку реакција на тозилирање, азидација и циклизација-адиција и беше употребен за синтеза на нови PUs. Беше синтетизиран нов линеарен P-1 на основа на јаглехидрат во реакција на 6 и 1,6-хексаметилен диизоцијанат (1,6-HDMI). Покрај тоа беа синтетизирани и три нови PUs (P-2, P-3 и P-4) во реакција на 6, изоамидно соединение (користено во различни моларни односи) и 1,6-HMDI. Термичките својства на новите PUs беа определени термогравиметриски (TG), нивната молекулска структура беше карактеризирана со FTIR, ${ }^{1} \mathrm{H}-$ и ${ }^{13} \mathrm{C}-\mathrm{NMR}$, додека молекуларната маса на некои од полимерите беше определена co GPC/SEC. Дополнително, површинските карактеристики на синтетизираните PUs беа определени со скенирачка електронска микроскопија (SEM).

Клучни зборови: поли(оксим-уретан); полиуретан; 1,6-хексаметилен диизоцијанат; изоманид; азид; диоксим; 1,2,3-триазол

\section{INTRODUCTION}

Polyurethanes (PUs), urethane (or carbamate) groups containing polymers, were firstly discovered in 1937 by Otto Bayer and co-workers and prepared by the reaction of monomers containing diisocyanate and hydroxyl groups. PUs offer various usages, such as furniture/insulating materi- 
als, fuel binders, sealants, materials for increasing crashworthiness, and agents for the controlled release of drugs or therapeutics [1-4]. Most monomers used in PUs' synthesis are petrol-based except when used for biomedical purposes, for which natural monomers are preferred. Additionally, PUs have hard and soft segments in their structure. The soft segment, which comes from a long carbon chain of a diol monomer, provides elasticity. In contrast, the hard segment, resulting from several carbon atoms in the diisocyanate monomer, contributes to strength and rigidity [2-9].

The design of new polymer materials from renewable resources has offered an enormous potential to replace the depleting fossil feedstock and is considered to be an environmental alternative [10]. 1,4:3,6-Dianhydrohexitols — three isomers (isosorbide, isomannide, and isoidide) of high importance in this context - were widely used as monomers and building blocks in polymer chemistry to prepare chiral polycondensates. They are thermally stable and easily available from cereal-based polysaccharides and provide stereochemical diversity [3, 11-15]. The synthesis of linear sugar-based PUs is generally accomplished by the reaction of sugarbased diols and diisocyanates in a varied range of conditions, either in solution or in bulk, leading to [AABB]-type PUs $[10,13]$. PUs from protected sugar derivatives and 1,6-hexamethylene diisocyanate (1,6-HMDI) have been reported [16].

1,2,3-Triazoles are a noteworthy class of heterocyclic compounds that have attracted a great deal of attention from chemists due to their potential biological activities, such as antiviral, antimicrobial, antiallergic, and anti-HIV activities and their applications in anticonvulsants, dyes, corrosion inhibitors, sensors, and photo-stabilizers [1723]. Only a few general methods for the synthesis of 1,2,3-triazoles have been described, i.e., a) Huisgen [3+2] 1,3-Dipolar Cycloaddition, b) Copper-Catalyzed Azide-Alkyne Cycloaddition $(\mathrm{Cu}-$ AAC) [20], c) Ruthenium-Catalyzed Azide-Alkyne Cycloaddition (RuAAC) [19], d) Dimroth reaction, as a cycloaddition of azides with active methylene compounds in the presence of basic conditions [24, 25]. A highly efficient copper(I)- or rutheniumcatalyzed method for the chemo- and regioselective-synthesis of 1,2,3-triazoles from organic azides and alkynes is the most frequently used. Besset et al. reported the investigation of their polyaddition by CuAAC in solution or by solvent and copper-free thermal Huisgen polyaddition of anhydrohexitols [26, 27].

As a member of the imine family, oximes, which are multifunctional materials containing an - $\mathrm{OH}$ group, are usually generated by the condensa- tion of hydroxylamine and aldehydes or ketones [28]. Although the reactions of oxime and isocyanate have been known since 1889 [29], poly(oxime-urethanes) were reported by Campbell et al. in 1959 [30]. In their study, poly(oxime-urethane) as a condensation polymer obtained from the reaction of diisocyanates (3,3'-dimethoxy-4,4'-biphenylene diisocyanate, methylene bis[4-phenyl isocyanate], hexamethylene diisocyanate) with four symmetrical dioximes (1,4-cyclohexanedione dioxime, dimethylglyoxime, terephthalaldehyde dioxime, and 2,6-pyridine dialdoxime) are reported. Similarly, poly(oxime-urethanes) are also prepared from the uncatalyzed polyaddition of multifunctional oximes and hexamethylene diisocyanate at ambient temperature [28]. Additionally, there are also studies on photochemical degradation of poly(oximeurethanes) used as amine photobase generators. These polymers can generate amines by decomposing the $\mathrm{N}-\mathrm{O}$ bond with the photolysis of oximeurethane linkage [31, 32]. Recently, Xu et al. reported the dynamic poly(oxime-urethanes) with excellent self-healing ability, malleability, and mechanical properties [33].

In this paper, we synthesized a new 1,2,3triazole-bridged ketoxime as a diol source from isomannide via tosylation, azidation, cyclization, and condensation reactions. The new poly(oximeurethanes) were generated from the polyaddition reaction of the new dioxime compound 6 with 1,6HMDI - a commercial diisocyanate. In addition to the two-component PUs, three-component PUs containing isomannide derivatives were also prepared. The thermal properties of all the polymeric materials were investigated by TG.

\section{EXPERIMENTAL}

\subsection{General Methods}

All the starting materials, solvents, and other chemicals were purchased from Merck, Alfa Aesar, or Sigma-Aldrich and used without further purification. The melting points were determined using a BI 9200 Branstead Electrothermal melting point apparatus with the open-capillary method and were uncorrected. The IR spectroscopy was carried out with a potassium bromide $(\mathrm{KBr})$ disc on a Perkin Elmer Spectrum 100 FTIR spectrophotometer. 1D and 2D NMR spectra $\left({ }^{1} \mathrm{H},{ }^{13} \mathrm{C}\right.$, NOESY, COSY, HSQC, and HMBC) were recorded on a Varian AS $400 \mathrm{MHz}$ spectrometer, which operated at $400 \mathrm{MHz}$ for ${ }^{1} \mathrm{H}$ nuclei and $100 \mathrm{MHz}$ for ${ }^{13} \mathrm{C} \mathrm{nu}-$ clei in deuterated chloroform $\left(\mathrm{CDCl}_{3}\right)$ or dimethyl sulphoxide (DMSO- $\left.d_{6}\right)$. The chemical shifts $(\delta)$ were given in parts per million (ppm) using the 
residue solvent peaks as references relative to tetramethylsilane as the internal standard. Coupling constants $(J)$ were presented in hertz $(\mathrm{Hz})$. The signals were abbreviated as a singlet, $\mathrm{s}$; doublet, $\mathrm{d}$; doublet-doublet, dd; triplet, t; and multiplet, $\mathrm{m}$. The high-resolution mass spectra (HRMS) analyses were performed on an Agilent 6230 TOF-MS equipped with Jet Stream ESI source operated in positive ion mode. All the IR, NMR, and MS spectra were offered in supplementary materials. All the reactions were monitored by thin-layer chromatography (TLC) using precoated silica gel G-60 $\mathrm{F}_{254}$ (Merck 5554) aluminum plates with detection under UV light $(254 \mathrm{~nm})$ and sprayed with $20 \%$ $\mathrm{H}_{2} \mathrm{SO}_{4}$ solution in water followed by heating at 120 ${ }^{\circ} \mathrm{C}$ or basic $\mathrm{KMnO}_{4}$ solution. Mesh silica gel $(70 \times 230$, Merck 7734) was used for open column chromatographic studies with the indicated solvent mixture.

\subsection{Synthesis of 1,4:3,6-dianhydro-2,5-di-O-(p- toluenesulfonyl)-D-mannitol (3)}

Tosyl chloride ( $45.5 \mathrm{~g}, 0.239 \mathrm{~mol}, 3.5$ eq.) in pyridine $(70 \mathrm{ml})$ was slowly added to $1,4: 3,6$ dianhydro-D-mannitol (isomannide) (1) (10.0 g, $0.0684 \mathrm{~mol})$ in pyridine $(30 \mathrm{ml})$ in an ice bath. The reaction mixture was stirred at ambient temperature for $24 \mathrm{~h}$. The reaction was monitored by TLC. After $24 \mathrm{~h}$, the reaction mixture was added into $2 \mathrm{M}$ $\mathrm{HCl}$ and ice water and stirred at room temperature (rt) for $2 \mathrm{~h}$. The reaction was filtered and dried at rt. The residue was recrystallized from $\mathrm{MeOH}$. The compound 3 structure was elucidated by FTIR ( $\mathrm{KBr}$ disc, $\mathrm{cm}^{-1}$; Spectrum 1). Colorless solid, yield: $84 \%$; mp: $92-93{ }^{\circ} \mathrm{C}$ (lit.: $91-92{ }^{\circ} \mathrm{C}$ ) [34]. FTIR ( $\mathrm{KBr}$ disc, $\left.\mathrm{cm}^{-1}\right)$; 3006 (Aromatic $\mathrm{C}-\mathrm{H}$ ), 2936-2876 (alip. C-H), 1562, 1680 (arom., -C=C-), 1368, $1192\left(-\mathrm{SO}_{2^{-}}\right), 1086$ (C-O-C).

\subsection{Synthesis of 2,5-Diazido-2,5-dideoxy-1,4:3,6- dianhydro-L-iditol (4)}

Sodium azide (14.0 g, $0.215 \mathrm{~mol}, 8.0$ eq.) was dissolved in dimethylformamide (DMF), and it was added to the 1,4:3,6-dianhydro-2,5-di- $O$ tosyl-D-mannitol (3) $(15.0 \mathrm{~g}, 0.027 \mathrm{~mol})$ in DMF $(80 \mathrm{ml})$. The mixture was refluxed and stirred at $100{ }^{\circ} \mathrm{C}$ for $24 \mathrm{~h}$. After the 24 -h reflux, the reaction mixture was added into the ice water $(400 \mathrm{ml})$, and it was stirred for $2 \mathrm{~h}$. The mixture was extracted with dichloromethane $(\mathrm{DCM} ; 3 \times 50 \mathrm{ml})$, and the combined organic layers were washed with water $(100 \mathrm{ml})$, dried over anhydrous $\mathrm{Na}_{2} \mathrm{SO}_{4}$, and concentrated under reduced pressure. The residue was subjected to column chromatography on silica gel eluting with DCM [34]. The compound 4 structure was elucidated by FTIR ( $\mathrm{KBr}$ disc, $\mathrm{cm}^{-1}$; Spectrum 2). Colorless syrup, yield: $72 \%$. FTIR ( $\mathrm{KBr}$ disc, $\left.\mathrm{cm}^{-1}\right) ; 2950,2882$ (aliph. C-H), $2104\left(-\mathrm{N}_{3}\right)$, 1094 (C-O-C).

\subsection{Synthesis of $\left\{1-\left[2^{\prime}, 5^{\prime}\right.\right.$-Dideoxy-1', $4^{\prime}: 3^{\prime}, 6^{\prime}-$ dianhydro-L-iditol-2',5'-diyl]bis[5-methyl-1H- \\ 1,2,3-triazole-1,4-diyl]\}bis(ethan-1-one) (5)}

Anhydrous potassium carbonate $(8.80 \mathrm{~g}$, $0.0637 \mathrm{~mol}, 2.5$ eq.) was added into the solution of compound $4\left(\begin{array}{llll}5.0 & \mathrm{~g}, & 0.0255 \mathrm{~mol}\end{array}\right)$ and 2,4pentanedione $(7.9 \mathrm{ml}, 0.0764 \mathrm{~mol}, 3.0$ eq.) in 60 $\mathrm{ml} \mathrm{DMF}$, and then the mixture was continuously stirred at $80{ }^{\circ} \mathrm{C}$ for $4 \mathrm{~h}$. The progress of the reaction was monitored by TLC (Toluene-MeOH, 9:1). At the end of the reaction time, the reaction mixture was poured into $300 \mathrm{ml}$ of ice-water and stirred for $1 \mathrm{~h}$ for precipitation. The precipitate was filtered, washed with water, and air-dried. For further purification, the light-yellow solid was recrystallized from dichloromethane/hexane. The structure of compound $\mathbf{5}$ was determined by FTIR ( $\mathrm{KBr}$ disc, $\mathrm{cm}^{-1}$ ), ${ }^{1} \mathrm{H}-\mathrm{NMR},{ }^{13} \mathrm{C}-\mathrm{NMR}, 2 \mathrm{D}-\mathrm{NMR}$ (COSY, NOESY, HMBC and HSQC), and LC-MS (ESI-positive mode) spectra of (Spectrum 3-18). Colorless solid (5), yield: $89 \%$, mp: 181.5-182.0 ${ }^{\circ} \mathrm{C}$. FTIR $\left(\mathrm{KBr}\right.$ disc, $\left.\mathrm{cm}^{-1}\right) ; 2958,2884$ (aliph. C$\mathrm{H}), 1680(\mathrm{C}=\mathrm{O}), 1560,1422$ (triazole ring), 1080 $(\mathrm{C}-\mathrm{O}-\mathrm{C}) .{ }^{1} \mathrm{H}$ NMR $\left(400 \mathrm{MHz}, \mathrm{CDCl}_{3}\right) \delta 5.22(\mathrm{~s}$, $2 \mathrm{H}, \mathrm{H}-3^{\prime}$ and H-4'), $4.94\left(\mathrm{dd}, 2 \mathrm{H}, J_{I^{\prime} a, 2^{\prime}}=J_{5^{\prime}, 6^{\prime} a}=5.8\right.$ $\mathrm{Hz}, J_{1^{\prime} b, 2^{\prime}}=J_{5^{\prime} 6^{\prime} b}=2.8 \mathrm{~Hz}, \mathrm{H}-2^{\prime}$ and $\left.\mathrm{H}-5^{\prime}\right), 4.42(\mathrm{dd}$, $2 \mathrm{H}, J_{l^{\prime} a, l^{\prime} b}=J_{6^{\prime} a, 6^{\prime} b}=10.0 \mathrm{~Hz}, \mathrm{H}-1^{\prime} \mathrm{a}$ and H-6'a), 4.27 (dd, $2 \mathrm{H}, \mathrm{H}-\mathrm{1}^{\prime} \mathrm{b}$ and $\left.\mathrm{H}-6^{\prime} \mathrm{b}\right), 2.58$ (s, 12H, $2 \times$ triazole- $\mathrm{CH}_{3}$ and $2 \times$ acetyl- $\left.\mathrm{CH}_{3}\right)$ ppm; ${ }^{13} \mathrm{C}$ NMR $(100$ $\left.\mathrm{MHz}, \mathrm{CDCl}_{3}\right) ; \delta 194.1(2 \times \mathrm{C}=\mathrm{O}), 143.6(2 \times \mathrm{C}-4)$, $136.6(2 \times \mathrm{C}-5), 88.2\left(\mathrm{C}-3^{\prime}\right.$ and $\left.\mathrm{C}-4^{\prime}\right), 72.3\left(\mathrm{C}-1^{\prime}\right.$ and $\left.\mathrm{C}-6^{\prime}\right), 62.8\left(\mathrm{C}-2^{\prime}\right.$ and $\left.\mathrm{C}-5^{\prime}\right), 27.6(2 \times$ acetyl$\left.\mathrm{CH}_{3}\right), 9.0\left(2 \times\right.$ triazole- $\left.\mathrm{CH}_{3}\right)$ ppm. TOF-ESIMS: calc'd for $\mathrm{C}_{16} \mathrm{H}_{21} \mathrm{~N}_{6} \mathrm{O}_{4}[\mathrm{M}+\mathrm{H}]: 361.1624$, found: 361.1597; calc'd for $\mathrm{C}_{16} \mathrm{H}_{20} \mathrm{~N}_{6} \mathrm{O}_{4} \mathrm{Na}$ [M+Na]: 383.1444, found: 383.1413 .

\subsection{Synthesis of $\left\{1-\left[2^{\prime}, 5^{\prime}-\right.\right.$ Dideoxy-1', $4^{\prime}: 3^{\prime}, 6^{\prime}-$} dianhydro-L-iditol-2',5'-diyl]bis[5-methyl-1H-1,2,3triazole-1,4-diyl]\}bis(ethan-1-one) dioxime (6)

Hydroxylamine hydrochloride (4.82 g, $0.0693 \mathrm{~mol}, 5.0$ eq.) and sodium acetate trihydrate $(5.66 \mathrm{~g}, 0.0416 \mathrm{~mol}, 3.0 \mathrm{eq})$ were added into the solution of compound $5(5.0 \mathrm{~g}, 0.0139 \mathrm{~mol})$ in 60 $\mathrm{ml}$ absolute ethanol, and the reaction mixture was stirred at $80^{\circ} \mathrm{C}$ for $4 \mathrm{~h}$. At the end of the reaction, the solvent was evaporated under reduced pressure, and the solid residue was triturated with boiling 
water three times. Then, the white solid (6) was obtained and air-dried. The structure of compound 6 was elucidated by FTIR ( $\mathrm{KBr}$ disc, $\left.\mathrm{cm}^{-1}\right),{ }^{1} \mathrm{H}$ NMR, ${ }^{13} \mathrm{C}-\mathrm{NMR}$, and 2D-NMR (COSY, NOESY, HMBC, and HSQC), and TOF-ESIMS spectra of (Spectra 19-25) yield: $83 \%$, mp: $234-235{ }^{\circ} \mathrm{C}$. FTIR (KBr disc, $\left.\mathrm{cm}^{-1}\right) ; 3350$ (-OH), 2958-2864 (aliph. C-H), $1628(\mathrm{C}=\mathrm{N}), 1560$ and 1422 (arom. triazole ring, $\mathrm{C}=\mathrm{C}), 1094$ (C-O-C). ${ }^{1} \mathrm{H}$ NMR (400 MHz, DMSO- $d 6) \delta 11.10(\mathrm{~s}, 2 \mathrm{H},=\mathrm{N}-\mathrm{OH}), 5.21(\mathrm{~s}$, $2 \mathrm{H}, \mathrm{H}-3^{\prime}$ and $\left.\mathrm{H}-4^{\prime}\right), 5.20\left(\mathrm{dd}, 2 \mathrm{H}, J_{l^{\prime} a, 2^{\prime}}=J_{5^{\prime}, 6^{\prime} a}=5.6\right.$ $\mathrm{Hz}, J_{I^{\prime} b 2^{\prime}}=J_{5^{\prime}, 6^{\prime} b}=3.2 \mathrm{~Hz}, \mathrm{H}-2^{\prime}$ and $\left.\mathrm{H}-5^{\prime}\right), 4.37$ (dd, $2 \mathrm{H}, J_{I^{\prime} a, 1^{\prime} b}=J_{6^{\prime} a, \sigma^{\prime} b}=10.2 \mathrm{~Hz}, \mathrm{H}-1^{\prime} \mathrm{a}$ and H-6'a), 4.16 (dd, $2 \mathrm{H}, \mathrm{H}-1^{\prime} \mathrm{b}$ and $\left.\mathrm{H}-6^{\prime} \mathrm{b}\right), 2.50$ (s, 6H, $2 \times$ oxime$\left.\mathrm{CH}_{3}\right), 2.21\left(\mathrm{~s}, 6 \mathrm{H}, 2 \times\right.$ triazole- $\left.\mathrm{CH}_{3}\right) \mathrm{ppm} ;{ }^{13} \mathrm{C}$ NMR (100 MHz, DMSO- $d \sigma): \delta 149.6(2 \times \mathbf{C}=\mathrm{N}-)$, $141.4(2 \times \mathrm{C}-4), 131.6(2 \times \mathrm{C}-5), 87.8\left(\mathrm{C}-3^{\prime}\right.$ and $\mathrm{C}-$ $\left.4^{\prime}\right), 72.5\left(\mathrm{C}-1^{\prime}\right.$ and $\left.\mathrm{C}-6^{\prime}\right), 63.1\left(\mathrm{C}-2^{\prime}\right.$ and $\left.\mathrm{C}-5^{\prime}\right), 12.3$ $\left(2 \times\right.$ triazole- $\left.\mathrm{CH}_{3}\right), 9.7\left(2 \times\right.$ oxime- $\left.\mathrm{CH}_{3}-\mathrm{C}=\mathrm{N}-\right)$ ppm. TOF-ESIMS: calc'd for $\mathrm{C}_{16} \mathrm{H}_{23} \mathrm{~N}_{8} \mathrm{O}_{4}[\mathrm{M}+\mathrm{H}]$ : 391.1842, found: 391.1961 .

\subsection{Synthesis of the two-component polyurethanes $(P-1)$ and $(P-5)$}

\subsubsection{Synthesis of the new polyurethane (P-1)}

1,6-Hexamethylene diisocyanate ( $1.30 \mathrm{~g}, 1.0$ eq.) was added into the solution of compound $\mathbf{6}$ $(0.0077 \mathrm{~mol})$ in anhydrous DMF and stirred under argon at $80{ }^{\circ} \mathrm{C}$ for $6 \mathrm{~h}$. The mixture was then cooled to room temperature and poured into cold methanol. The precipitate was filtered, washed with methanol, and air-dried. The polymeric material was further dried in a vacuum oven at $80{ }^{\circ} \mathrm{C}$ for five days. The compound $\mathrm{P}-1$ structure was determined by FTIR ( $\mathrm{KBr}$ disc, $\mathrm{cm}^{-1}$ ), ${ }^{1} \mathrm{H}-\mathrm{NMR}$ (400 $\mathrm{MHz}$, DMSO-d6), and ${ }^{13} \mathrm{C}-\mathrm{NMR}$ (100 $\mathrm{MHz}$, DMSO- $d 6$ ) spectra of (Spectra 27-29) yield $71 \%$.

\subsubsection{Synthesis of the two-component PU (P-5) containing isomannide only}

Only isomannide (1.695 g, $0.012 \mathrm{~mol}$ ) as a diol source was reacted with 1,6-HMDI (1.95 g, $0.012 \mathrm{~mol}, 1.0 \mathrm{eq}$.) according to the synthesis procedure of P-1, yield $64 \%$. ${ }^{1} \mathrm{H}-\mathrm{NMR}(400 \mathrm{MHz}$, DMSO- $d \sigma$ ), and ${ }^{13} \mathrm{C}-\mathrm{NMR}$ (100 MHz, DMSO-d6) spectra of (Spectra 42-45).

\subsubsection{General procedure for the synthesis of the three-component PUs (P-2-4)}

1,6-HMDI was added into the solution of compound $\mathbf{6}$ and isomannide (used in the different molar ratio $25 \%, 50 \%$ and $75 \%$, Table 1) in anhydrous DMF, and it was stirred under argon at 80 ${ }^{\circ} \mathrm{C}$ for $6 \mathrm{~h}$. The mixture was then allowed to cool to room temperature and poured into cold methanol. The precipitate was filtered, washed with methanol, and air-dried. The polymeric material was further dried in a vacuum oven at $80^{\circ} \mathrm{C}$ for five days. The structures of the three-component PUs (P-2-4) compounds were elucidated by FTIR ( $\mathrm{KBr}$ disc, $\mathrm{cm}^{-1}$ ), ${ }^{1} \mathrm{H}-\mathrm{NMR}$ (400 MHz, DMSO-d6), and ${ }^{13} \mathrm{C}-$ NMR (100 MHz, DMSO-d6) spectra of (Spectrum 30-41).

\section{Table 1}

The composition as an equivalent and yields of two- and three-component PUs

\begin{tabular}{ccccc}
\hline \hline & $\begin{array}{c}\text { Compound } \\
\text { 6 }\end{array}$ & $\begin{array}{c}\text { 1,6- } \\
\text { HMDI }\end{array}$ & Isomannide & $\begin{array}{c}\text { Yield } \\
(\%)\end{array}$ \\
\hline P-1 & 1.00 & 1.00 & - & 71 \\
P-2 & 0.75 & 1.00 & 0.25 & 68 \\
P-3 & 0.50 & 1.00 & 0.50 & 62 \\
P-4 & 0.25 & 1.00 & 0.75 & 72 \\
P-5 & - & 1.00 & 1.00 & 64 \\
\hline \hline
\end{tabular}

\section{RESULTS AND DISCUSSION}

To obtain the diol source (6) (Scheme 1), firstly, isomannide was converted into ditosylate ester (3) in $84 \%$ yield and then into diazido derivative (4) with $72 \%$ yield by a substitution reaction by inversion of the configuration according to the literature $[34,35]$. In the FTIR spectra of $\mathbf{3}$ available in the supplementary material, a characteristic peaks at $3006 \mathrm{~cm}^{-1}$ (aromatic $\mathrm{C}-\mathrm{H}$ ), 1562 $\mathrm{cm}^{-1}, 1680 \mathrm{~cm}^{-1}$ (aromatic, $-\mathrm{C}=\mathrm{C}-$ ), $1368 \mathrm{~cm}^{-1}$, $1192 \mathrm{~cm}^{-1}\left(-\mathrm{SO}_{2}-\right)$ were observed.

The FTIR spectra of $\mathbf{4}$ and $\mathbf{5}$ were investigated to observe that the peaks of tosyl groups in the structure disappeared and a strong azide peak (4) at $2104 \mathrm{~cm}^{-1}$ appeared. The bis-triazole- derivative 5 was obtained in $89 \%$ yield via the Dimroth reaction of 4 and 2,4-pentanedione in the presence of $\mathrm{K}_{2} \mathrm{CO}_{3}$. For the structural elucidation, FTIR, ${ }^{1} \mathrm{H}-,{ }^{13} \mathrm{C}-\mathrm{NMR}$, NOESY, HSQC, HMBC, and mass spectra of addition-activated methylene groups of compound $\mathbf{5}$ to azides were performed. The disappearance of the characteristic azide peak in $2104 \mathrm{~cm}^{-1}$ in the FTIR spectrum and the observation of carbonyl peak at $1680 \mathrm{~cm}^{-1}$ indicated that the cyclization reaction was completed. 


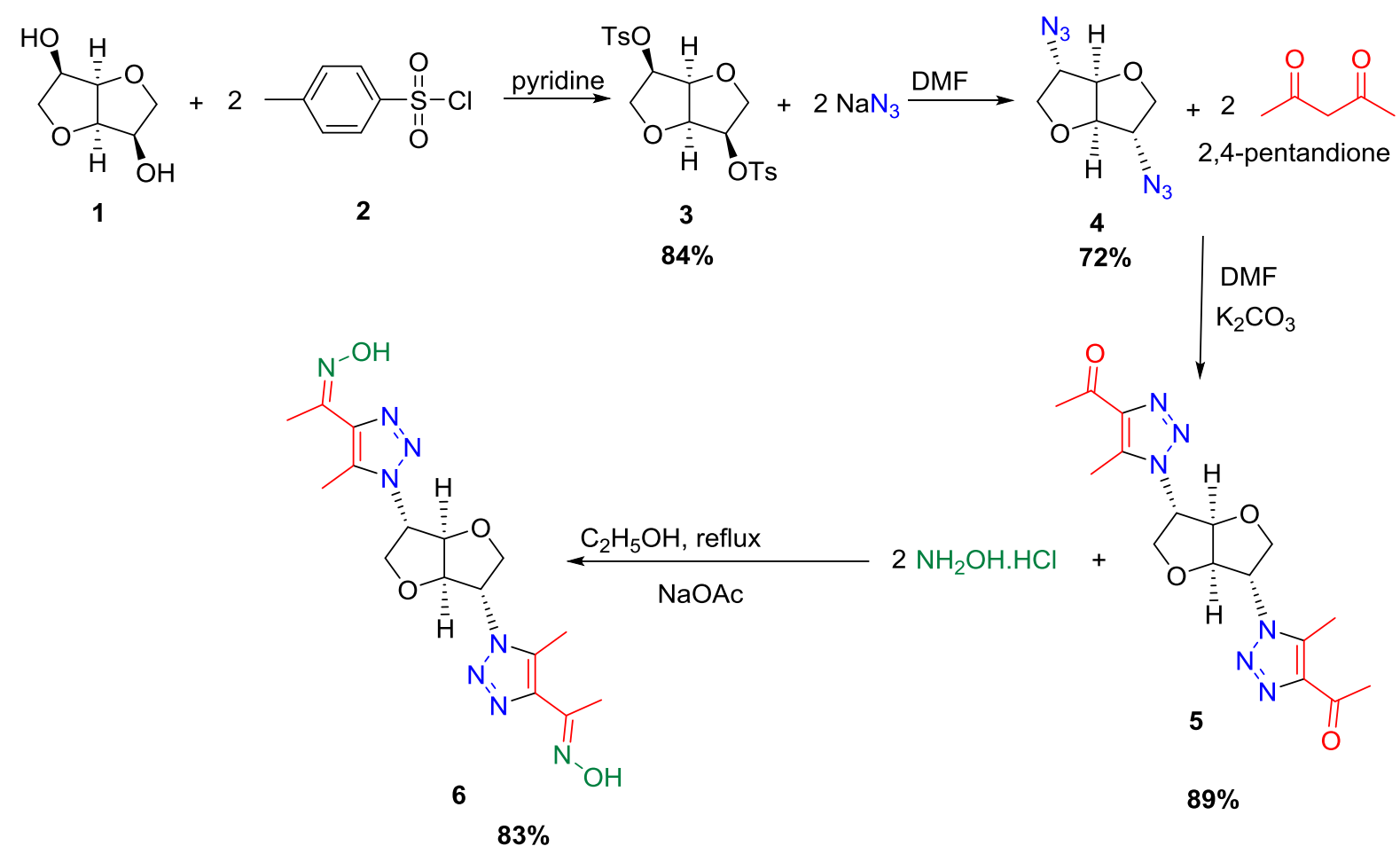

Scheme 1. Synthesis of new dioxime compound 6 used as a diol source

Compound $\mathbf{5}$, which is not found in the literature, appears to have the same triazole groups in the molecular structure, with the two sides of the molecule being symmetrical as depicted in Scheme 2. In addition to the protons of the bicyclic ring structure, twelve protons of the two triazole rings bounded acetyl and methyl also exhibited sharp singlet peaks at $2.58 \mathrm{ppm}$. Geminal diastereotopic methylene protons (H-1a,b'-H-6a,b') were observed at $4.44 / 4.26 \mathrm{ppm}$ with $J \sim 10 \mathrm{~Hz}$ as an ABX pattern. The singlet peak of $\mathrm{H}-3^{\prime}$ and $\mathrm{H}-4^{\prime}$ ' was observed at $5.22 \mathrm{ppm}$. It was interesting to observe the interac- tion of these protons with each other and with other vicinal protons.

The interactions of $\mathrm{H}-2^{\prime} / \mathrm{H}-3^{\prime}$ and $\mathrm{H}-4^{\prime} / \mathrm{H}-5^{\prime}$ protons were unobservable due to the transorientation (Scheme 2). In the COSY spectrum, the correlation, typical of singlet two protons of $\mathrm{H}-3^{\prime}$ and $\mathrm{H}-4^{\prime}$ at $5.22 \mathrm{ppm}$, was not observed with $\mathrm{H}-3^{\prime}$ and $\mathrm{H}-4^{\prime}$, respectively (Spectra 9-10). The correlation of the two protons $\left(\mathrm{H}-2^{\prime}\right.$ or $\left.\mathrm{H}-5^{\prime}\right)$ at $4.94 \mathrm{ppm}$ as $d d$ was shown with $\mathrm{H}-1^{\prime} \mathrm{a}$ or $\mathrm{H}-6^{\prime} \mathrm{a}$ at $4.44 \mathrm{ppm}$ and $\mathrm{H}-1^{\prime} \mathrm{b}$ or $\mathrm{H}-6^{\prime} \mathrm{b}$ at $4.22 \mathrm{ppm}$, respectively. Further correlation of $\mathrm{H}-\mathrm{1}^{\prime}$ and $\mathrm{H}-\mathrm{6}^{\prime}$ protons was also observed very clearly.

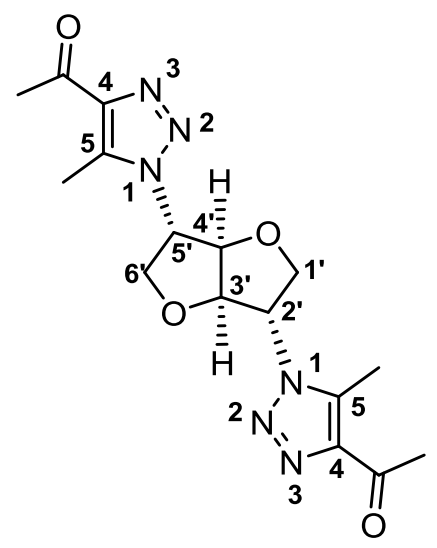

(i)

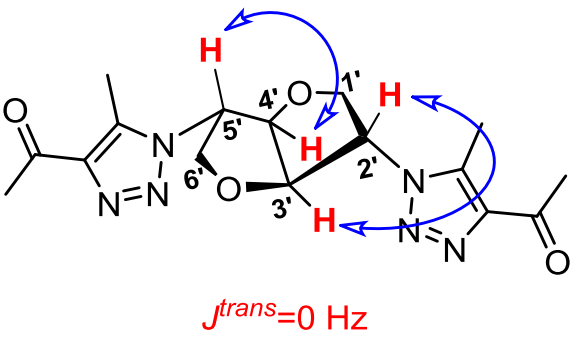

(ii)

Scheme 2. (i) Numbered atoms for NMR analysis; (ii) confirmed conformation structure via ${ }^{1} \mathrm{H}$ NMR of compound 5 
In the NOESY spectrum (Spectra 11-12), as expected for the structure of compound $\mathbf{5}$ in Scheme 3, strong NOE signals were detected for $\mathrm{H}-3^{\prime} / \mathrm{H}^{\prime} 4^{\prime}$ at $5.22 \mathrm{ppm}$ with $\mathrm{H}-2^{\prime} / \mathrm{H}-5^{\prime}, \mathrm{H}-1^{\prime} / \mathrm{H}-6^{\prime}$, and triazole- $\mathrm{CH}_{3}$ at $2.58 \mathrm{ppm}$. Furthermore, we observed the correlation signals of $\mathrm{H}-2^{\prime} / \mathrm{H}-5^{\prime}$ with $\mathrm{H}-1^{\prime} / \mathrm{H}-6^{\prime}$ and each other.

The HSQC and HMBC spectra were used to fully assign the in-chain carbons of 5 . The HSQC correlation showed ABX protons at 4.42 and 4.27 ppm with carbon atoms at $72.3 \mathrm{ppm}$ (Spectra 1314). The correlation of carbon atoms at $62.8 \mathrm{ppm}$ with protons at $4.94 \mathrm{ppm}$ indicated C-2' and C-5'; similarly, the proton-carbon interactions were also found (Scheme 3). The carbons in the triazole ring were observed at $143.6(2 \times \mathrm{C}-4)$ and $136.6(2 \times \mathrm{C}$ 5) ppm (Scheme 2). The HMBC spectrum (Spectra 15-17), although not a very clear spectrum, cor- roborates some data from HSQC, NOESY, and ${ }^{13} \mathrm{C}$ NMR. One of the most prominent peaks at ${ }^{13} \mathrm{C}$ NMR (Spectrum 8) was the carbonyl peak at 194.1 ppm, whereas the others of C-4 and C-5 of the triazole rings were observed at 143.6 and $136.6 \mathrm{ppm}$, respectively. It was understood that the peak of the C-5 carbon, to which the methyl group in the triazole ring is attached, shifted from $136.6 \mathrm{ppm}$ to the upfield zone. The peak at $143.6 \mathrm{ppm}$ shifted to the downfield because of the electrons attracted from the ring of the acetyl group fused to the triazole ring. The signals of the methyl groups and the methyl groups of two acetyl groups were also observed to be fused to a triazole ring at $9.0 \mathrm{ppm}$ and $27.6 \mathrm{ppm}$, respectively. The $[\mathrm{M}+\mathrm{H}]$ and $[\mathrm{M}+\mathrm{Na}]$ peaks were determined in the mass spectrum using liquid chromatography (LC)-electrospray ionization method (ESI) (Spectrum 18).

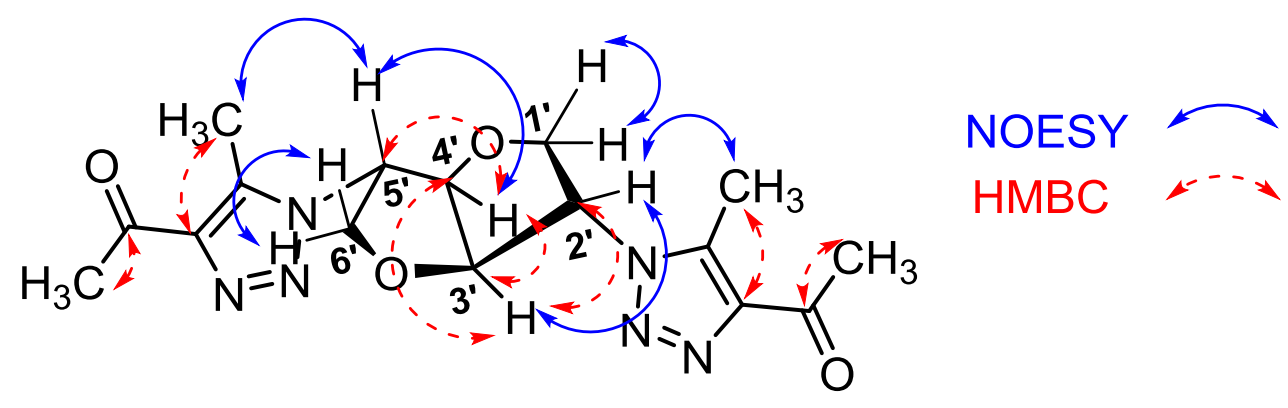

Scheme 3. NOESY and HMBC correlations of compound 5

Compound 6 was obtained from the reaction of compound $\mathbf{5}$ with hydroxylamine hydrochloride in $83 \%$ yield and was subsequently used as a diol source (Scheme 1). The FTIR spectra of $\mathbf{6}$ displayed bands of mainly $3350 \mathrm{~cm}^{-1}$ and $1628 \mathrm{~cm}^{-1}$, which arose from the stretching vibration of the $-\mathrm{OH}$ and $\mathrm{C}=\mathrm{N}-$ bonds of the oxime groups, respectively. The investigation of the overlapped FTIR spectrum 20 of $\mathbf{5}$ and $\mathbf{6}$ showed that the peaks of carbonyl peak of $\mathbf{5}$ disappeared, and strong oxime $\mathrm{OH}$ peaks of $\mathbf{6}$ appeared at $3350 \mathrm{~cm}^{-1}$. The compound $\mathbf{6}$ structure was elucidated by ${ }^{1} \mathrm{H}$ and ${ }^{13} \mathrm{C}$ NMR spectrum (Spectra 19-24). The ${ }^{1} \mathrm{H}$ NMR spectrum displayed a proton signal for an oxime $\mathrm{OH}$ at $11.10 \mathrm{ppm}$. Furthermore, the observation of the imine $(\mathrm{C}=\mathrm{N}-)$ carbon peaks at 149.6 ppm in the ${ }^{13} \mathrm{C}$ NMR spectrum evidenced the oxime groups in the structure.

Comparing the chemical shift value of the methyl groups adjacent to the imine groups at 9.7 ppm of $\mathbf{6}$ with acetyl methyl groups in compound $\mathbf{5}$ revealed that they shifted to an upfield zone. Besides, the observation of the $[\mathrm{M}+\mathrm{H}]$ peak in the mass spectrum obtained by the LC-ESI method also proved to be the exact determination of the structure of the target compound (Spectrum 25).

\subsection{Preparation of PUs}

In our study, polymers P-1 to $\mathbf{P - 5}$ were prepared from the reaction of compound $\mathbf{6}$ and/or isomannide with diisocyanate 1,6-HMDI, respectively. The polymerization of diisocyanates with various ratios of compound 6 and/or isomannide in Table 1 was carried out by polyaddition in DMF at $80^{\circ} \mathrm{C}$ for $6 \mathrm{~h}$ without catalysts with good yields, as shown in Scheme 4. All of the obtained PUs except for P-5 [36] were synthesized for the first time. P-5 was further synthesized as a reference for determining the peaks of isomannide in NMR spectra of other new PUs. 


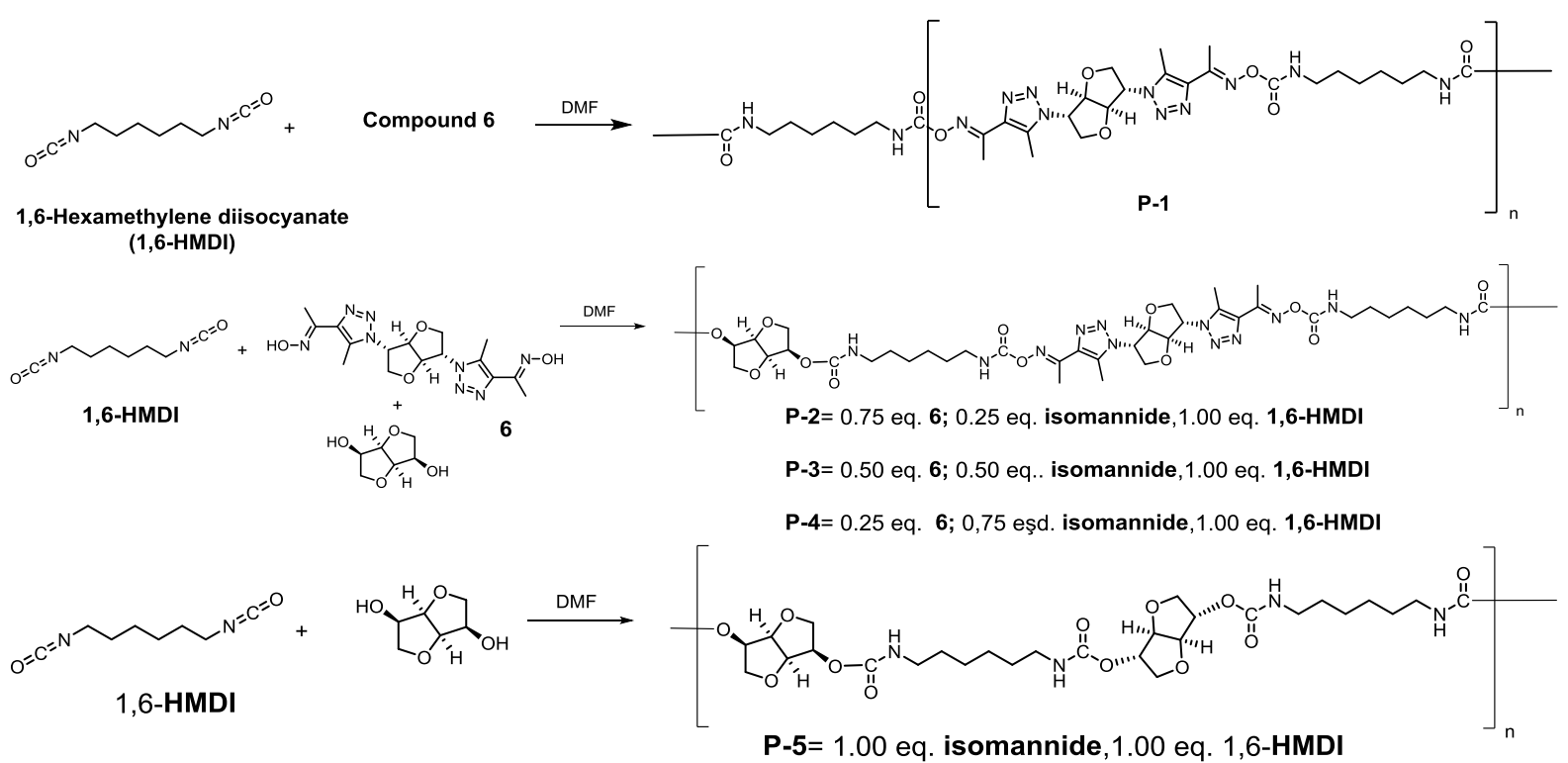

Scheme 4. Preparation of novel two- and three-component PUs

Two-component PUs were prepared from dioxime 6 as the diol source and 1,6-HMDI (Scheme 4). The new three-component PUs were obtained from compound $\mathbf{6}$ and isomannide in different molar equivalents, as given in Table 1, with diisocyanate 1,6-HMDI using the method in the synthesis of the two-component PUs (Scheme 4). FTIR and NMR spectroscopy were used to determine the structure of two- and three-component new polyurethane compounds.

\subsection{Characterization of PUs}

\subsubsection{FTIR analysis}

When the FTIR spectra (Spectra 26 and 42) of the two-component polyurethane derivative (P-1 and $\mathbf{P - 5}$ ) was recorded, the characteristic peak of cumulated diene $-\mathrm{N}=\mathrm{C}=\mathrm{O}$ around $2250 \mathrm{~cm}^{-1}$ was absent, indicating that all of the diisocyanate starting materials reacted. The PUs exhibited a distinctive broad amide $-\mathrm{NH}-$ peak at $3298-3240 \mathrm{~cm}^{-1}$ and strong carbonyl stretching absorption bands of amide at $1740-1744 \mathrm{~cm}^{-1}$ and $1662-1668 \mathrm{~cm}^{-1}$. Hydrogen-bonded $\mathrm{N}-\mathrm{H}$ bending bands were observed at $1502-1530 \mathrm{~cm}^{-1}$. The asymmetric and symmetric $\mathrm{C}-\mathrm{H}$ stretching bands were detected at $2860-2936 \mathrm{~cm}^{-1}$, and the band at $1092-1094 \mathrm{~cm}^{-1}$ was attributed to the C-O-C dissymmetry stretching vibrations of the etheric group in the ring of isomannide. These data showed that the twocomponent PU in Scheme 4 was formed. Further structural elucidation was attained from NMR spectroscopy.
Similar absorption bands in the FTIR spectra of the three-component PUs (P-2-P-4) were observed as well (Spectra 30, 34, 38). The bands at 2982 and $2858 \mathrm{~cm}^{-1}$ were attributed to C-H stretching vibrations. The amide group $(-\mathrm{NH}-)$ peak at $3322 \mathrm{~cm}^{-1}$ and hydrogen-bonded $\mathrm{NH}$ stretching bands were seen at $1510-1538 \mathrm{~cm}^{-1}$, and a carbonyl group $(\mathrm{C}=\mathrm{O})$ stretching transmittance at 1722 $1744 \mathrm{~cm}^{-1}$. The C-O-C stretching vibration bands were observed in the area from 1068 to $1096 \mathrm{~cm}^{-1}$.

\subsection{2. ${ }^{1} \mathrm{H}$ NMR analysis}

In the ${ }^{1} \mathrm{H}$ and ${ }^{13} \mathrm{C}$ NMR spectra of PUs presented in the supplemental material, DMSO- $d_{6}$ was used as the solvent. The spectra were provided comparatively for a better understanding of the differences and similarities between the NMR spectra of the polymers (Figure 1).

From the comparison of the ${ }^{1} \mathrm{H}$ NMR spectra of the two-component P-1, P-5, the following results were obtained (Scheme 4; Spectra 27, 28, 43, and 44): (a) The starting material, isomannide derivative dioxime compound $\mathbf{6}$, was provided for an easier determination of the peaks in the polymer chain. (b) The observed peaks around $11.10 \mathrm{ppm}$ come from the group $=\mathrm{N}-\mathrm{OH}$ in the spectra of the polymers indicated that the $-\mathrm{OH}$ groups remained at the terminal position. (c) The peaks occurring between 4.00 and $5.50 \mathrm{ppm}$ were assigned to the bicyclic ring protons of isomannide of the dioxime compound. (d) Two different methyl groups were also detected at 2.00 to $3.00 \mathrm{ppm}$ in both the monomer and the polymer. (e) In P-1, apart from the protons of compound $\mathbf{6}$, the $-\mathrm{CH}_{2}$ - groups from the 
aliphatic hexamethylene were resonated at about $1.00-1.50 \mathrm{ppm}$.

The ${ }^{1} \mathrm{H}$ NMR spectra (Scheme 4, Spectra 27, $28,31,32,35,36,39,40,43$, and 44) of hexamethylene diisocyanate (HMDI)-derivative threecomponent polyurethanes P-2, P-3, P-4 with P-5 and two-component polymer $\mathbf{P}-\mathbf{1}$ and isomannide were provided in the supplementary materials. While the protons in the isomannide ring appeared between about 3.50 and $3.90 \mathrm{ppm}$ and at approximately $4.90 \mathrm{ppm}$, the methylene protons of HMDI appear between 1.00 and $1.50 \mathrm{ppm}$ using the spectrum of two-component P-5. The oxime -OH peak at about $11.00 \mathrm{ppm}$ was also not observed.

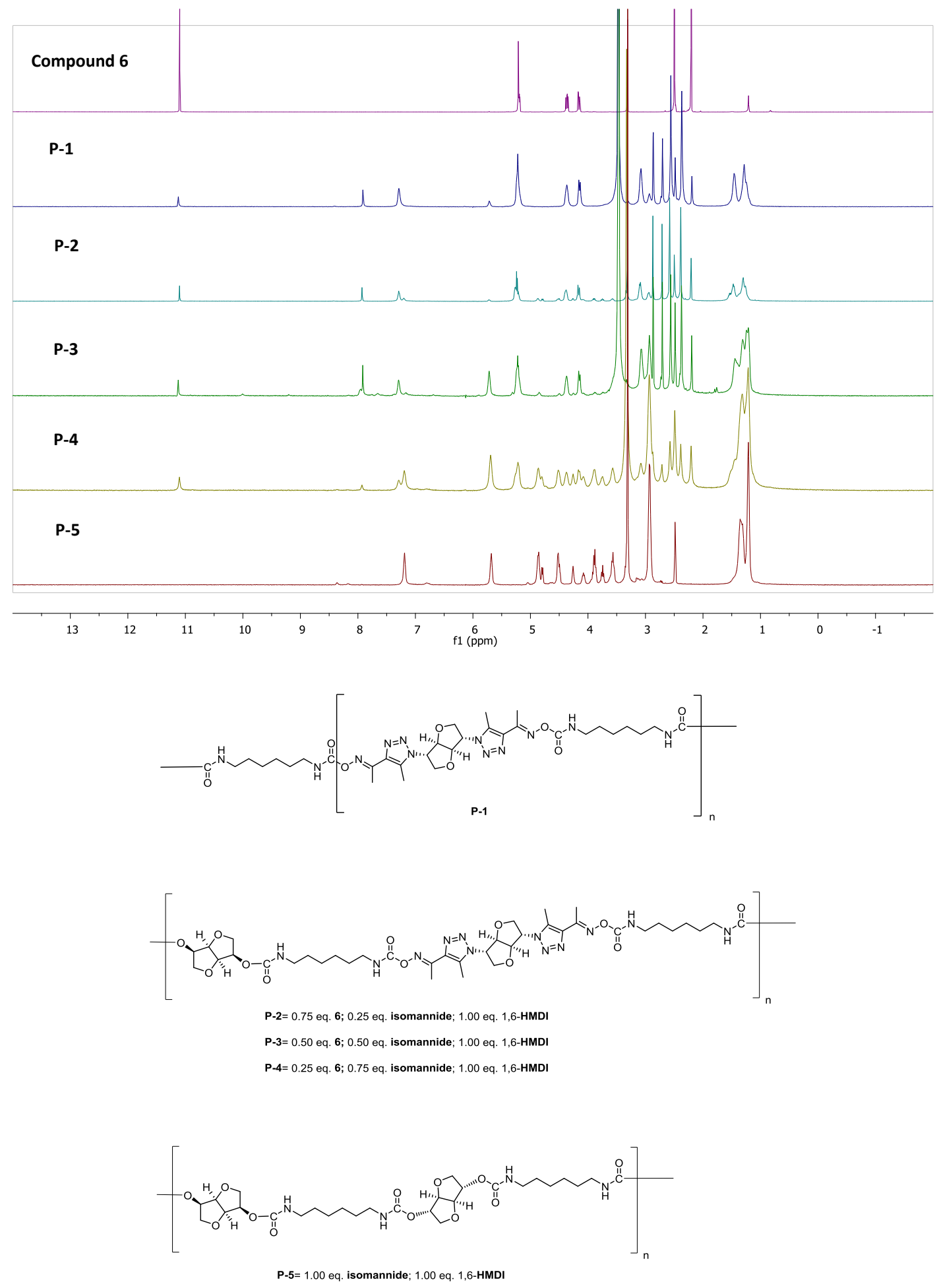

Fig. 1. Comparative ${ }^{1} \mathrm{H}$ NMR spectra of compound 6, P-1 to P-5 (400 MHz, DMSO- $d_{6}$ ) 


\subsection{3. ${ }^{13} \mathrm{C}$ NMR analysis}

The comparison of the ${ }^{13} \mathrm{C}$ NMR spectra of two-component P-1 (Fig. 2, Spectrum 29) manifested that the carbon atoms of the triazole ring of the isomannide derivative dioxime compound $\mathbf{6}$ and the $-\mathrm{C}=\mathrm{N}-$ peaks resonated at $130-150 \mathrm{ppm}$, the bicyclic isomannide ring at $60-90 \mathrm{ppm}$, and the methyl peaks at $10-15 \mathrm{ppm}$. The carbonyl resonances appeared between 160 and $165 \mathrm{ppm}$ and methylene $\left(-\mathrm{CH}_{2}-\right)$ carbons in the P-1 compound at 30-40 ppm.
For comparative purposes, ${ }^{13} \mathrm{C}$ NMR spectra (Spectra 29, 33, 37, 41, and 45) of the threecomponent products of hexamethylene diisocyanate-derived polyurethanes $\mathbf{P - 1 ,} \mathbf{P - 2}, \mathbf{P}-\mathbf{3}, \mathbf{P}-\mathbf{4}$, and $\mathbf{P}-5$.are given in Figure 2. Urethane carbonyl peaks were observed at about $162 \mathrm{ppm}$, bicyclic ring carbons in the range of $60-90 \mathrm{ppm}$, methyl peaks around 10-15 ppm, and methylene groups of hexamethylene diisocyanate in the range of 25-30 ppm.

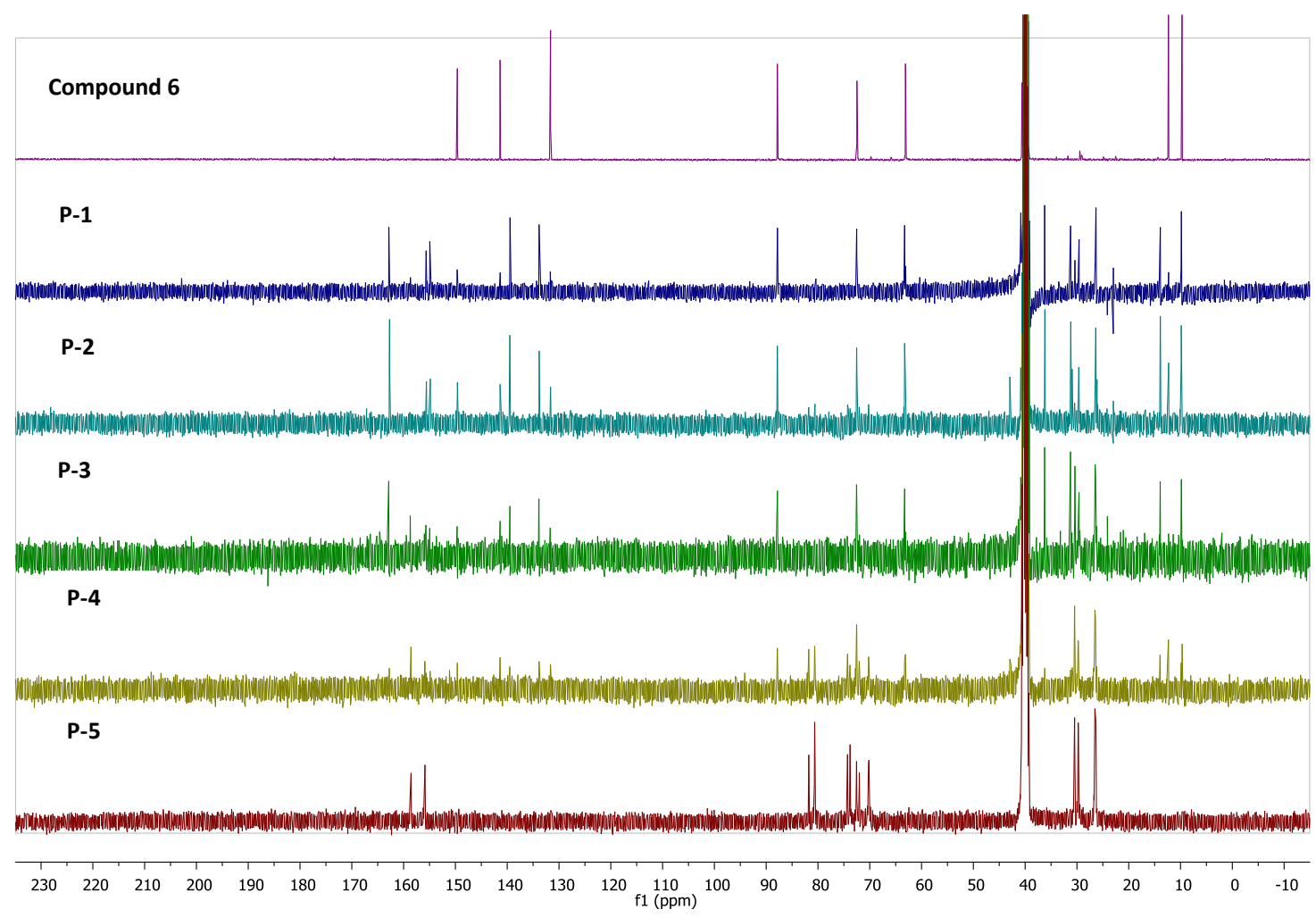

Fig. 2. Comparative ${ }^{13} \mathrm{C}$ NMR spectra of compound 6, P-1 to P-5 (100 MHz, DMSO- $\left.d_{6}\right)$

\subsubsection{Thermogravimetric analysis}

Thermogravimetric (TG) measurements of the PU samples were performed with PerkinElmer Diamond TA/TGA from $25{ }^{\circ} \mathrm{C}$ to $600{ }^{\circ} \mathrm{C}$ at a 10 ${ }^{\circ} \mathrm{C}$ heating rate at a constant flow rate of $20 \mathrm{ml} / \mathrm{min}$ under nitrogen gas. The thermal stabilities of PUs were evaluated by TGA-dTG analysis. According to the TG diagram of PUs in Figure 3, the thermal degradation of aliphatic PUs starts at around 200 ${ }^{\circ} \mathrm{C}$ [37]. Although the increase was observed for the first degradation peak, the temperatures of the second degradation and $50 \%$ of the mass were decreased, and the thermal stability of the PU matrix was decreased by increasing the amount of isomannide and decreasing the amount of compound $\mathbf{6}$. The number of residues after the thermal degradation was slightly decreased (Table 2).

Both the thermal stability of the PU matrix and the residues after the thermal degradation were decreased by increasing the amount of isomannide and decreasing the amount of compound $\mathbf{6}$. 


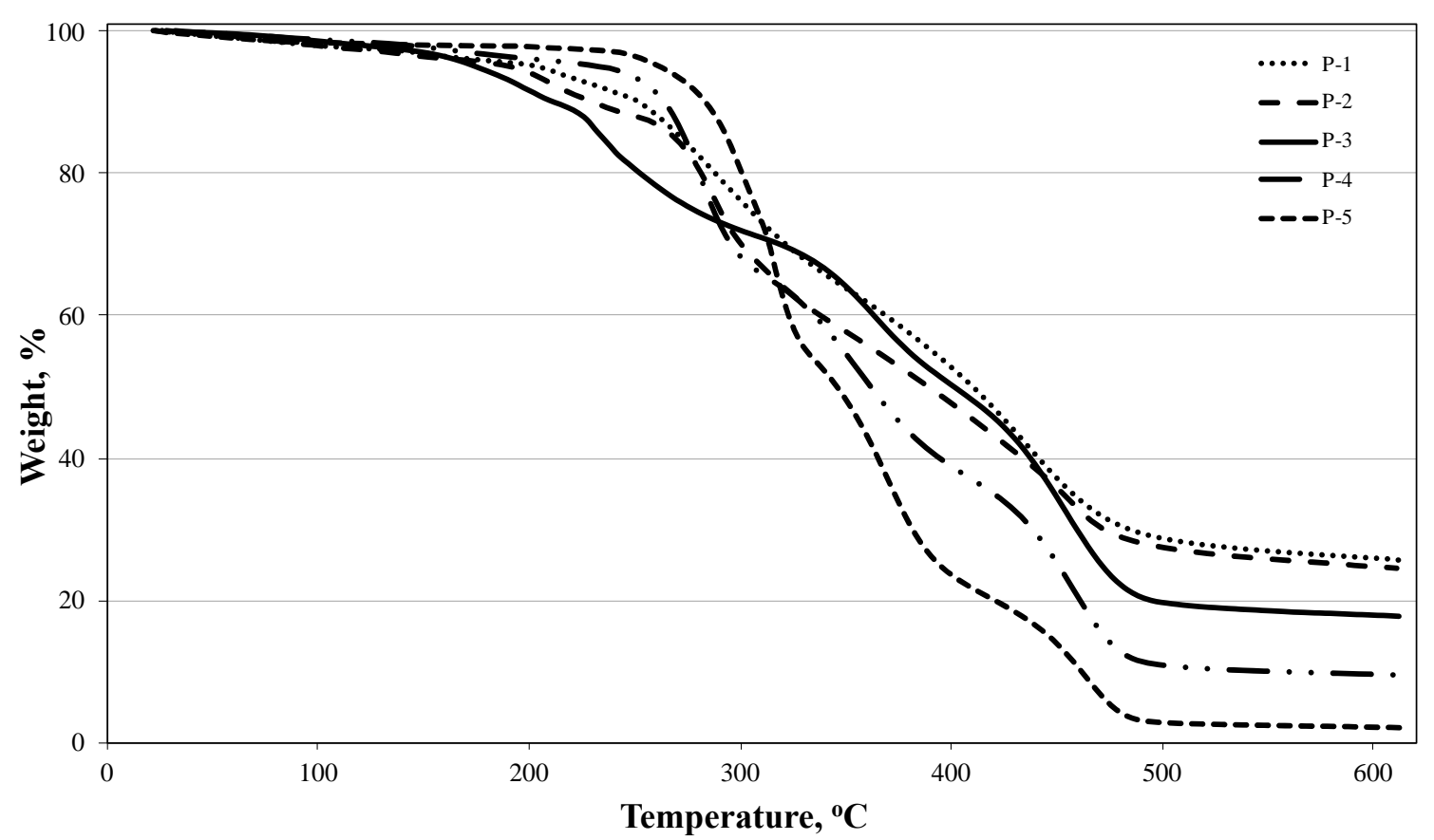

Fig. 3. TGA diagrams for P-1, P-2, P-3, P-4, and P-5

Table 2

TGA results of PUs

\begin{tabular}{ccccc}
\hline $\begin{array}{c}\text { Sample } \\
\text { Code }\end{array}$ & $\begin{array}{c}\text { Degradation } \\
\left.\text { (First peak, }{ }^{\circ} \mathbf{C}\right)\end{array}$ & $\begin{array}{c}\text { Degradation } \\
\left.\text { (Second peak, }{ }^{\circ} \mathbf{C}\right)\end{array}$ & $\begin{array}{c}\mathbf{5 0 \%} \text { of } \\
\text { degradation }\end{array}$ & $\begin{array}{c}\text { Residue } \\
(\boldsymbol{\%})\end{array}$ \\
\hline P-1 & 216 and 286 & 436 & 411 & 25 \\
P-2 & 211 and 286 & 451 & 391 & 24 \\
P-3 & 192 and 232 & 362 and 452 & 402 & 17 \\
P-4 & 278 & 363 and 458 & 363 & 9 \\
P-5 & 318 & 373 and 463 & 348 & 2 \\
\hline \hline
\end{tabular}

\subsection{Gel permeation chromatography (GPC)}

Number average molecular weights and polydispersity index (PDI) of PUs were determined by gel permeation chromatography (GPC) on an Agilent GPC Model 1100 Instrument incorporating a pump and a refractive index detector using the mobile phase consisting of $N, N$-dimethylformamide (DMF) containing $0.1 \mathrm{M} \mathrm{LiBr}$ at a flow rate of 0.7 $\mathrm{ml} / \mathrm{min}$. Before the injection, the polymer solutions were filtered using a $0.45 \mu \mathrm{m}$ PFTE filter. According to the linear poly(methyl methacrylate) standards for calibration, the calibration range of $\mathrm{mp}=2,500-270,000 \mathrm{~g} / \mathrm{mol}$ was employed. The results compiled in Table 3 manifest that the molecular weights ranged from 9,700 to 34,000 , corresponding to a high degree of polymerization [38]. The molecular weight of the HMDI system PU was decreased by increasing isomannide and decreasing HMDI.
Table 3

Molecular weights of PU series

\begin{tabular}{ccc}
\hline \hline & $\left(\mathbf{M}_{\mathbf{w}}\right)$ & PDI $\left(\mathbf{M}_{\mathbf{w}} / \mathbf{M}_{\mathbf{n}}\right)$ \\
\hline $\mathbf{P - 1}$ & 34,000 & 1,889 \\
\hline $\mathbf{P - 2}$ & 32,000 & 1,600 \\
\hline $\mathbf{P - 3}$ & 9,700 & 1,386 \\
\hline \hline
\end{tabular}

\subsection{Scanning electron microscopy (SEM) of PU matrices}

SEM photographs were produced using a JEOL SEM-7100-EDX instrument at a magnification of $1000 \times$ or $1500 \times$. The reaction of the aliphatic compound transformed the morphology to a bulky structure. The exchange between compound 6 and isomannide also affected the morphology of the PU matrices. 
A porous and bulky polymer matrix was observed as a result of the HMDI and compound 6 . The diameters of these cavities ranged from around $100 \mathrm{~nm}$ to $2000 \mathrm{~nm}$ (Fig. $4 \mathrm{a}$ and b).

Both the porous surfaces with lesser cavities and the bulky surfaces were observed due to add- ing $50 \%$ isomannide instead of compound 6 in the polymerization mixture. In Figure 4, a rough and bulky polymer matrix was observed as a result of 1,6-HMDI and isomannide. The polymer matrix acquired a stricter structure.
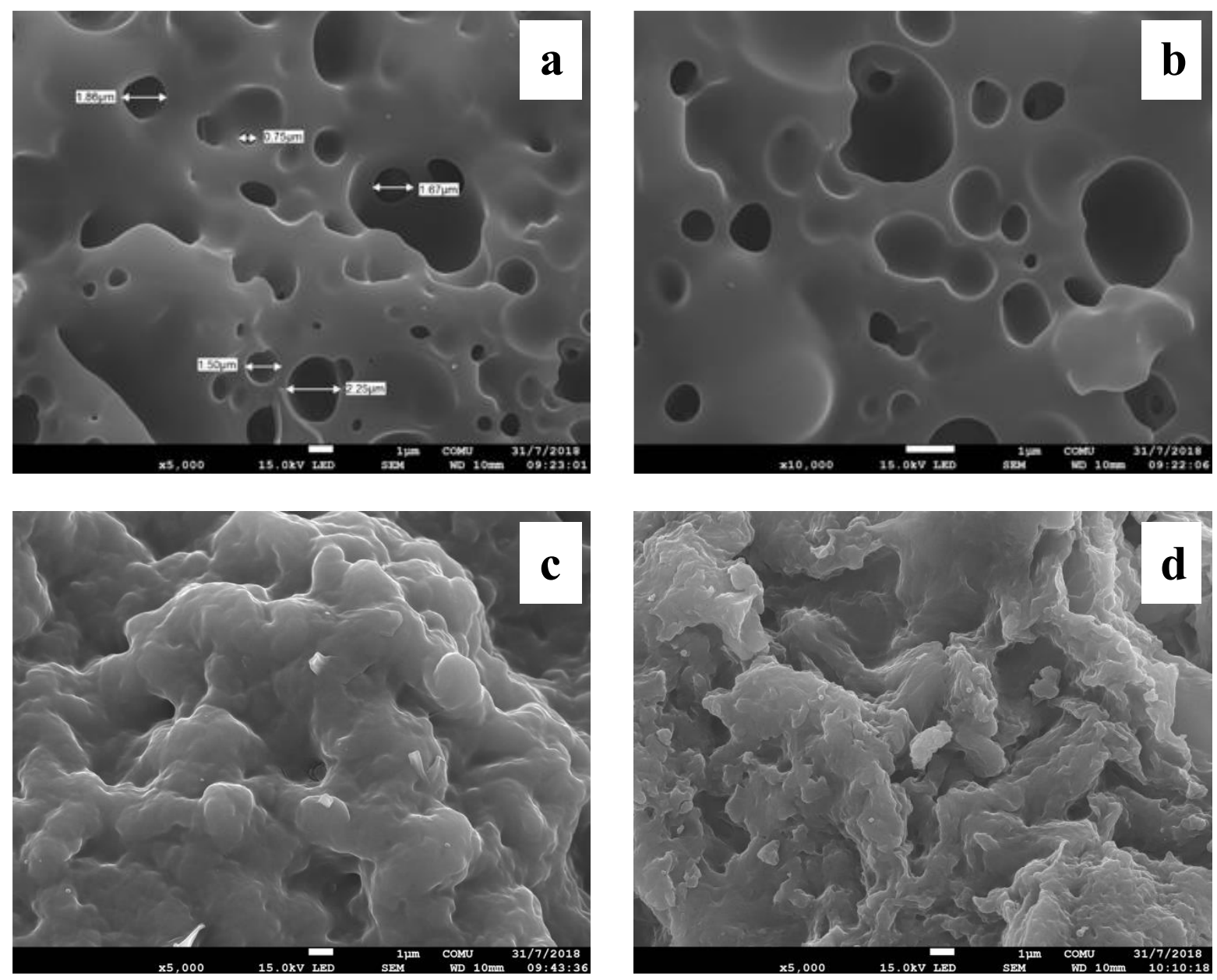

Fig. 4. Scanning electron micrographs of: a) P-1 at a magnification of $5000 \times$; b) P-1 at a magnification of $10000 \times$; c) P-3 at a magnification of $5000 \times$; and $\mathbf{d}) \mathbf{P}-5$ at a magnification of $5000 \times$

\section{CONCLUSION}

In the present research, we described biobased isomannide-derived new polymers synthesized from HMDI via a simple one-pot polyaddition reaction. Isomannide-derived 1,2,3-triazole bridged bis(ketoxime) (compound 6) was used as a diol source in different ratios for the synthesis of linear poly(ketoxime-urethane). This isomannidederived bis(ketoxime) was synthesized from azide with 2,4-pentanedione by a Dimroth reaction. Modern techniques, such as FTIR, NMR, MS, GPC, TG, and SEM, were employed for the structural elucidation of the new molecules/polymers and their physical properties. During the last few years, it has been realized from the studies that the application areas of the biobased polymers have been gradually increasing. Although the related literature does not incorporate many application areas for linear 1,2,3-triazole-bridged poly(ketoxime-urethanes), it is clear that these new polymers will provide researchers with a different perspective, especially on polymeric biomaterial development because of the versatile functions of triazoles.

Declaration of conflicting interests. The authors declare that there is no conflict of interest.

Acknowledgments. This study was supported by the Research Projects Coordination Office at Manisa Celal Bayar University (Project Number: 2016-060). 


\section{REFERENCES}

[1] F. Zafar, S. Eram, Polyurethane, InTech, 978-953-510726-2, Croatia (2012).

[2] S. L. Cooper, J. Guan, Advances in Polyurethane Biomaterials, Woodhead Publishing, 0081006225, 2016.

[3] M. Ionescu, Chemistry and Technology of Polyols for Polyurethanes, iSmithers Rapra Publishing, 978-184735-035-0, United Kingdom, 2005.

[4] N. Kébir, S. Nouigues, P. Moranne, F. Burel, Nonisocyanate thermoplastic polyurethane elastomers based on poly(ethylene glycol) prepared through the transurethanization approach, Journal of Applied Polymer Science, 134 (45), 44991 (2017).

DOI: doi.org/10.1002/app.44991

[5] L. Jiang, Z. Ren, W. Zhao, W. Liu, H. Liu, C. Zhu, Synthesis and structure/properties characterizations of four polyurethane model hard segments, Royal Society Open Science, 5 (7), 180536 (2018).

DOI: doi.org/10.1098/rsos.180536

[6] J. Pavličević, M. Špírková, O. Bera, M. Jovičić, K. M. Szécsényi, J. Budinski-Simendić, The influence of bentonite and montmorillonite addition on thermal decomposition of novel polyurethane/organoclay nanocomposites, Macedonian Journal of Chemistry and Chemical Engineering, 32 (2), 319-330 (2013). DOI: dx.doi.org/10.20450/mjcce.2013.442

[7] N. Adam, G. Avar, H. Blankenheim, W. Friederichs, M. Giersig, E. Weigand, M. Halfmann, F. W. Wittbecker, D. R. Larimer, U. Maier, Polyurethanes, Ullmann's Encyclopedia of Industrial Chemistry, 29, 546-600 (2000).

[8] L. Nagy, M. Nagy, B. Vadkerti, L. Daróczi, G. Deák, M. Zsuga, S. Kéki, Designed polyurethanes for potential biomedical and pharmaceutical applications: Novel synthetic strategy for preparing sucrose containing biocompatible and biodegradable polyurethane networks, Polymers, 11 (5), 825 (2019). DOI: doi.org/10.3390/polym11050825

[9] J. Pavličević, M. Špírková, S. Sinadinović-Fišer, J. Budinski-Simendić, O. Govedarica, M., Janković, The influence of organoclays on the morphology, phase separation and thermal properties of polycarbonate-based polyurethane hybrid materials, Macedonian Journal of Chemistry and Chemical Engineering, 32 (1), 151-161 (2013). DOI: dx.doi.org/10.20450/mjcce.2013.144

[10] J. A. Galbis, M. d. G. García-Martín, M. V. De Paz, E. Galbis, Synthetic polymers from sugar-based monomers, Chemical Reviews, 116 (3), 1600-1636 (2015). DOI: doi.org/10.1021/acs.chemrev.5b00242

[11] M. M'sahel, A. Elmahdi, R. Medimagh, E. Drockenmuller, M. Said Zina, Synthesis and characterization of novel biosourced building blocks from isosorbide, Designed Monomers and Polymers, 19 (2), 108-118 (2016).

DOI: doi.org/10.1080/15685551.2015.1124317

[12] M. D. Zenner, Y. Xia, J. S. Chen, M. R. Kessler, Polyurethanes from isosorbide-based diisocyanates, ChemSusChem, 6 (7), 1182-1185 (2013).

DOI: doi.org/10.1002/cssc. 201300126
[13] F. Fenouillot, A. Rousseau, G. Colomines, R. SaintLoup, J.-P. Pascault, Polymers from renewable 1,4: 3,6dianhydrohexitols (isosorbide, isomannide and isoidide): A review, Progress in Polymer Science, 35 (5), 578-622 (2010). DOI: doi.org/10.1016/j.progpolymsci.2009.10.001

[14] J. A. Galbis, M. De Gracia García-Martín, M. V. De Paz, E. Galbis, Bio-Based Polyurethanes from Carbohydrate Monomers. Y1lmaz, F., InTech, 978-953-513546-3, United Kingdom, (2017).

[15] M.-Y. Lu, A. Surányi, B. Viskolcz, B. Fiser, Molecular design of sugar-based polyurethanes, Croatica Chemica Acta, 91 (3), 1-9 (2018). DOI: doi.org/10.5562/cca3328

[16] R. Garcon, C. Clerk, J.-P. Gesson, J. Bordado, T. Nunes, S. Caroco, P. Gomes, M. M. Da Piedade, A. Rauter, Synthesis of novel polyurethanes from sugars and 1, 6hexamethylene diisocyanate, Carbohydrate Polymers, 45 (2), 123-127 (2001). DOI: doi.org/10.1016/S0144-8617(00)00323-4

[17] G. Jin, J. Zhang, D. Fu, J. Wu, S. Cao, One-pot, threecomponent synthesis of 1,4,5-trisubstituted 1,2,3triazoles starting from primary alcohols, European Journal of Organic Chemistry, (28), 5446-5449 (2012). DOI: doi.org/10.1002/ejoc.201200830

[18] H. Singh, J. Sindhu, J. M. Khurana, Synthesis of biologically as well as industrially important 1,4,5trisubstituted-1,2,3-triazoles using a highly efficient, green and recyclable DBU- $\mathrm{H}_{2} \mathrm{O}$ catalytic system, $R S C$ Advances, 3 (44), 22360-22366 (2013). DOI: $10.1039 / \mathrm{C} 3 \mathrm{RA} 44440 \mathrm{~F}$

[19] S. Kantheti, R. Narayan, K. Raju, The impact of 1,2,3triazoles in the design of functional coatings, $R S C$ Advances, 5 (5), 3687-3708 (2015). DOI: $10.1039 / \mathrm{C} 4 \mathrm{RA} 12739 \mathrm{~K}$

[20] E. Halay, E. Ay, E. Şalva, K. Ay, T. Karayıldırım, Synthesis of triazolylmethyl-linked nucleoside analogs via combination of azidofuranoses with propargylated nucleobases and study on their cytotoxicity, Chemistry of Heterocyclic Compounds, 54 (2), 158-166 (2018). DOI: doi.org/10.1007/s10593-018-2248-4

[21] J. Huo, H. Hu, M. Zhang, X. Hu, M. Chen, D. Chen, J. Liu, G. Xiao, Y. Wang, Z. Wen, A mini review of the synthesis of poly-1,2,3-triazole-based functional materials, $R S C$ Advances, 7 (4), 2281-2287 (2017). DOI: $10.1039 / \mathrm{C} 6 \mathrm{RA} 27012 \mathrm{C}$

[22] K. Ay, B. Ispartaloğlu, E. Halay, E. Ay, İ. Yaşa, T. Karayldırım, Synthesis and antimicrobial evaluation of sulfanilamide- and carbohydrate-derived 1,4-disubstitued1,2,3-triazoles via click chemistry, Medicinal Chemistry Research, 26 (7), 1497-1505, (2017). DOI: doi.org/10.1007/s00044-017-1864-3

[23] S. G. Agalave, S. R. Maujan, V. S. Pore, Click chemistry: 1,2,3-triazoles as pharmacophores, Chemistry - An Asian Journal, 6 (10), 2696-2718 (2011). DOI: doi.org/10.1002/asia.201100432

[24] I. F. Cottrell, D. Hands, P. G. Houghton, G. R. Humphrey, S. H. Wright, An improved procedure for the preparation of 1-benzyl-1H-1,2,3-triazoles from benzyl azides, Journal of Heterocyclic Chemistry, 28 (2), 301304 (1991). DOI: doi.org/10.1002/jhet.5570280216 
[25] A. Paula Freitas, M. Fernanda, J. Proença, B. L. Booth, Synthesis of 5-azido-4-cyanoimidazole and its reaction with active methylene compounds, Journal of Heterocyclic Chemistry, 32 (2), 457-462 (1995). DOI: doi.org/10.1002/jhet.5570320212

[26] C. Besset, S. Binauld, M. Ibert, P. Fuertes, J.-P. Pascault, E. Fleury, J. Bernard, E. Drockenmuller, Copper-catalyzed vs thermal step growth polymerization of starch-derived $\alpha$-azide- $\omega$-alkyne dianhydrohexitol stereoisomers: to click or not to click?, Macromolecules, 43 (1), 17-19 (2009). DOI: doi.org/10.1021/ma9024784

[27] C. Besset, J. Bernard, E. Fleury, J.-P. Pascault, P. Cassagnau, E. Drockenmuller, R. J. Williams, Biosourced networks from thermal polyaddition of a starchderived $\alpha$-azide- $\omega$-alkyne $\mathrm{AB}$ monomer with an $\mathrm{A} 2 \mathrm{~B} 2$ aliphatic cross-linker, Macromolecules, 43 (13), 56725678 (2010). DOI: doi.org/10.1021/ma100770t

[28] W.-X. Liu, C. Zhang, H. Zhang, N. Zhao, Z.-X. Yu, J. $\mathrm{Xu}$, Oxime-based and catalyst-free dynamic covalent polyurethanes, Journal of the American Chemical Society, 139 (25), 8678-8684 (2017). DOI: doi.org/10.1021/jacs.7b03967

[29] H. Goldschmidt, Zur Kenntniss der Oxime, Berichte der Deutschen Chemischen Gesellschaft, 22 (2), 3101-3114 (1889). DOI: doi.org/10.1002/cber.188902202241

[30] T. W. Campbell, V. S. Foldi, R. G. Parrish, Condensation polymers from diisocyanates and dioximes, Journal of Applied Polymer Science, 2 (4), 81-85 (1959). DOI: doi.org/10.1002/app.1959.070020412

[31] S. I. Hong, T. Kurosaki, M. Okawara, Syntheses of polyurethanes derived from oximes and their photodegradation, Journal of Polymer Science, Part A-1: Polymer Chemistry, 10 (11), 3405-3419 (1972). DOI: doi.org/10.1002/pol.1972.170101125
[32] E. C. Buruiana, M. Olaru, B. C. Simionescu, Photobasegenerating new polyurethanes with oxime-urethane groups in the main chain, Journal of Applied Polymer Science, 94 (6), 2324-2332 (2004).

DOI: doi.org/10.1002/app.21194

[33] W.-X. Liu, Z. Yang, Z. Qiao, L. Zhang, N. Zhao, S. Luo, J. Xu, Dynamic multiphase semi-crystalline polymers based on thermally reversible pyrazole-urea bonds, Nature Communications, 10 (1), 1-8 (2019). DOI: doi.org/10.1038/s41467-019-12766-6

[34] L.-Y. Chen, S. Guillarme, C. Saluzzo, Dianhydrohexitols: new tools for organocatalysis. Application in enantioselective Friedel-Crafts alkylation of indoles with nitroalkenes, ARKIVOC, 3, 227-244 (2013). DOI: doi.org/10.3998/ark.5550190.0014.318

[35] T. G. Barros, S. Pinheiro, J. Williamson, A. Tanuri, M. Gomes Jr, H. S. Pereira, R. Brindeiro, J. B. Neto, O. Antunes, E. M. Muri, Pseudo-peptides derived from isomannide: inhibitors of serine proteases, Amino Acids, 38 (3), 701-709 (2010). DOI: doi.org/10.1007/s00726-009-0273-4

[36] M. Beldi, R. Medimagh, S. Chatti, S. Marque, D. Prim, A. Loupy, F. Delolme, Characterization of cyclic and non-cyclic poly-(ether-urethane)s bio-based sugar diols by a combination of MALDI-TOF and NMR, European Polymer Journal, 43 (8), 3415-3433 (2007). DOI: doi.org/10.1016/j.eurpolymj.2007.06.003

[37] H.-J. Kim, M.-S. Kang, J. C. Knowles, M.-S. Gong, Synthesis of highly elastic biocompatible polyurethanes based on bio-based isosorbide and poly (tetramethylene glycol) and their properties, Journal of Biomaterials Applications, 29 (3), 454-464 (2014). DOI: doi.org/10.1177/0885328214533737

[38] Z. S. Petrović, Polyurethanes from vegetable oils, Polymer Reviews, 48 (1), 109-155 (2008). DOI: doi.org/10.1080/15583720701834224 
